\title{
Bird assemblages on a Mediterranean sandy beach: a yearly study
}

\author{
Corrado Battisti
}

\begin{abstract}
Around the 2007 yearly cycle, we carried out a transect in a Mediterranean sandy beach (central Italy), a structurally oversimplified ecosystem, elaborating the data in six bimonthly periods and in three longitudinal habitat types. We observed 25 bird species. Assemblages appear heterogeneous at taxonomic-, phenological- and ecological-level. Also normalizing (Margalef index), in winter the beach hosted the richest assemblage, in summer-autumn the lowest. The inner dunal area appears the richest habitat type. Here, the presence of vegetation presumably permits the occurrence of a large availability of different trophic resources for different species. Beaches represent patchy ecosystems with a different availability of resources in space and time that host heterogeneous bird assemblages, different in their ecology and phenology around a yearly cycle.
\end{abstract}

Key words: Assemblages, species richness, Margalef index, abundance, beach, central Italy.

Riassunto - Comunità ornitica su una spiaggia mediterranea: uno studio su un ciclo annuale.

È stato condotto uno studio sull'avifauna di un ecosistema sabbioso costiero (Italia centrale) durante un ciclo annuale, elaborando i dati in sei bimestri e in tre fasce longitudinali (battigia, arenile, avanduna). Sono state rilevate 25 specie appartenenti a set estremamente eterogenei sotto il profilo tassonomico, ecologico e fenologico. Nel periodo invernale l'area ospita il maggior numero di specie, nel periodo estivo il minor numero. L'avanduna ha mostrato il maggior numero di specie, probabilmente per la presenza di vegetazione, di mosaicità ambientale e della disponibilità di risorse trofiche ad esse collegate (es., insetti, parti vegetali, detrito). Le spiagge sabbiose costituiscono ecosistemi dinamici ed eterogenei in termini di disponibilità di risorse nello spazio e nel tempo che ospitano comunità composte da set di specie marcatamente differenti nella loro ecologia e fenologia.

Parole chiave: comunità, ricchezza, abbondanza, spiagge, Italia centrale.

\footnotetext{
"Torre Flavia" LTER (Long Term Environmental Research) Station, Servizio Ambiente ("aree protette-parchi regionali"), Provincia di Roma, Via Tiburtina, 691, 00159 Roma, Italia E-mail: c.battisti@provincia.roma.it

(C) 2014 Corrado Battisti
}

Received: $1^{\text {st }}$ January 2014

Accepted for publication: $18^{\text {th }}$ June 2014

\section{INTRODUCTION}

Sandy beaches are transitional ecosystems linking marine and terrestrial systems in the coastal zone that provide nesting, foraging and stop-over areas for many species of vertebrates and invertebrates and harbour unique biological assemblages (Komar, 1998; McLachlan \& Brown, 2006). Moreover, these ecosystems are very peculiar with an oversimplification on their structure and a strong dynamism and seasonality. In these ecosystems, birds may occur in sandy beaches with specific patterns of abundance and richness reflecting the peculiar regime of resources, heterogeneous in space and dynamics in time. Nevertheless, studies on time fluctuations around yearly cycles are very scanty or limited to species of conservation concern (e.g., Brown \& McLachlan, 2002, Williams et alii, 2004).

The knowledge of the patterns of bird richness and abundance in sandy coastal areas could permit to better evaluate the role of these neglected ecosystems and develop appropriate conservation strategies (Schlacher et alii, 2006).

In this preliminary study, we aimed to test the hypothesis that a poor, patchy and structurally oversimplified ecosystem, as a Mediterranean sandy beach, may host a assemblages (sensu Fauth et alii, 1996) relatively poor in abundance, but rich and heterogeneous in species richness.

\section{STUDY AREA}

The study area was a sandy beach along the Tyrrhenian coast of Central Italy (Latium; Municipalities of Cerveteri and Ladispoli; $41^{\circ} 58^{\prime} \mathrm{N} ; 1^{\circ} 03^{\prime} \mathrm{E}$ ) included in the "Palude di Torre Flavia" natural Monument, a small protected coastal Mediterranean wetland (40 ha-wide; Special Area of Conservation, according to the EC Directive on the Conservation of Wild Bird 79/409/EEC), relict of a larger wetland drained and transformed by land reclamation in the last Century (Battisti, 2006; Battisti et alii, 2006).

Sandy beach is approximately $1,000 \mathrm{~m}$-long and shows a specific, semi-natural patchiness with a seashore area, an intermediate sandy zone and an inner dune area (Figs. 1 and 2). At landscape scale, this area shows char- 
acteristics of a remnant fragment of sandy beach embedded in an agricultural and urbanized matrix. Among the most significant disturbance factors and processes affecting this sandy beach, coastal erosion has a prevailing role, with irreversible destruction of geo-forms supporting plant communities (Acosta \& Izzi, 2006). On the beach, trampling, motor vehicle transit and others recreational activities resulted the main human-induced threats that promoting local floristic and structural vegetation changes (Battisti et alii, 2008). Climate of the study area is xeric-meso-Mediterranean (Tomaselli et alii, 1973; Blasi \& Michetti, 2005).

\section{METHODS}

\section{Protocol}

Data were obtained by carrying out a line transect method (Bibby et alii, 2000). A transect $1,000 \mathrm{~m}$ in length and approximately $30 \mathrm{~m}$ wide was covered along the Torre Flavia sandy beach in a parallel way in respect to the coastline. Some information would support the adequacy of the line transect method in this environment. Indeed, when compared to line transect method, mapping method (Bibby et alii, 2000) is very time consuming and suitable for more structured ecosystems and mainly for

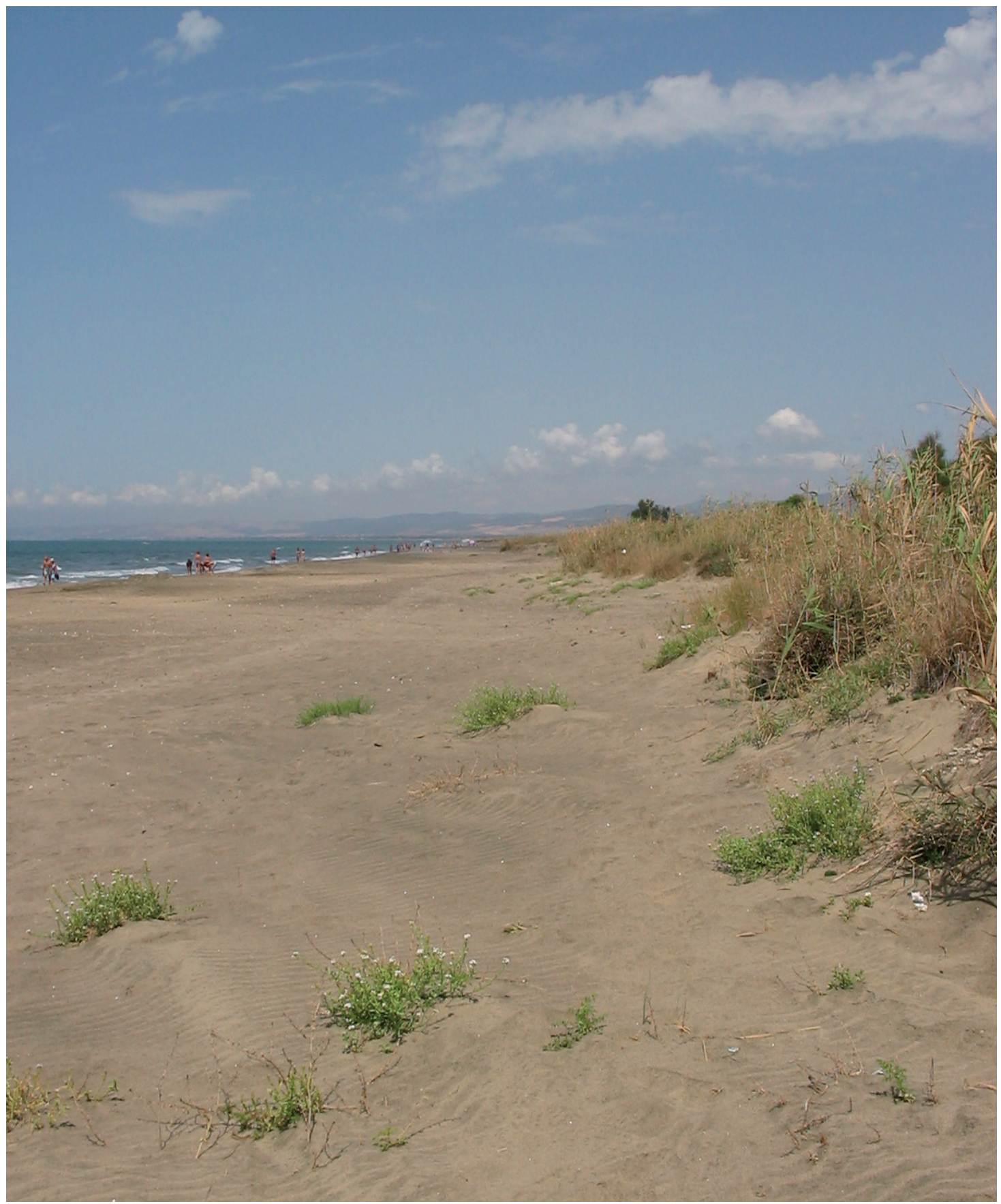

Fig. 1 - An overview of the study area where the line transect method has been carried out. (Un'immagine dell'area di studio ove è stato effettuato il censimento con il metodo del transetto lineare). Photo by Anna Guidi. 
territorial birds, while point counts (e.g., E.F.P.; Blondel et alii, 1970) do not permit to acquire a significant number of data in small linear fragments such as this sandy beach fragment (see also Sutherland, 2006).

Along the beach, we selected three longitudinal habitat types (hereafter, LHTs), from the seashore to the inner sides:

i) a seashore area (SEA), where the waves break on the sand;

ii) an intermediate sandy zone (SAN) with natural and anthropogenic debris (molluscan shells, seaweeds, pebbles, woods and others natural sediments, human garbages); iii) an inner embryonic shifting dunes (DUN) and annual vegetation of drift lines (with dominance of Agropyrum junceum, Sporobolus pungens, Euphorbia peplis, Otanthus maritimus, Medicago marina, Anthemis maritima, Eryngium maritimum, Pancratium maritimum), corresponding to 1210 and 2110 EC habitat types (92/43 "Habitat" Directive) (Guidi, 2006). Each longitudinal zone was approximately $10 \mathrm{~m}$ wide.

Around a yearly cycle, I walked along the transect three times per months from 10 January to 29 December 2007 , in the morning, within a hour after the dawn, for a total of 36 visits and 1,200 minutes of total sampling.

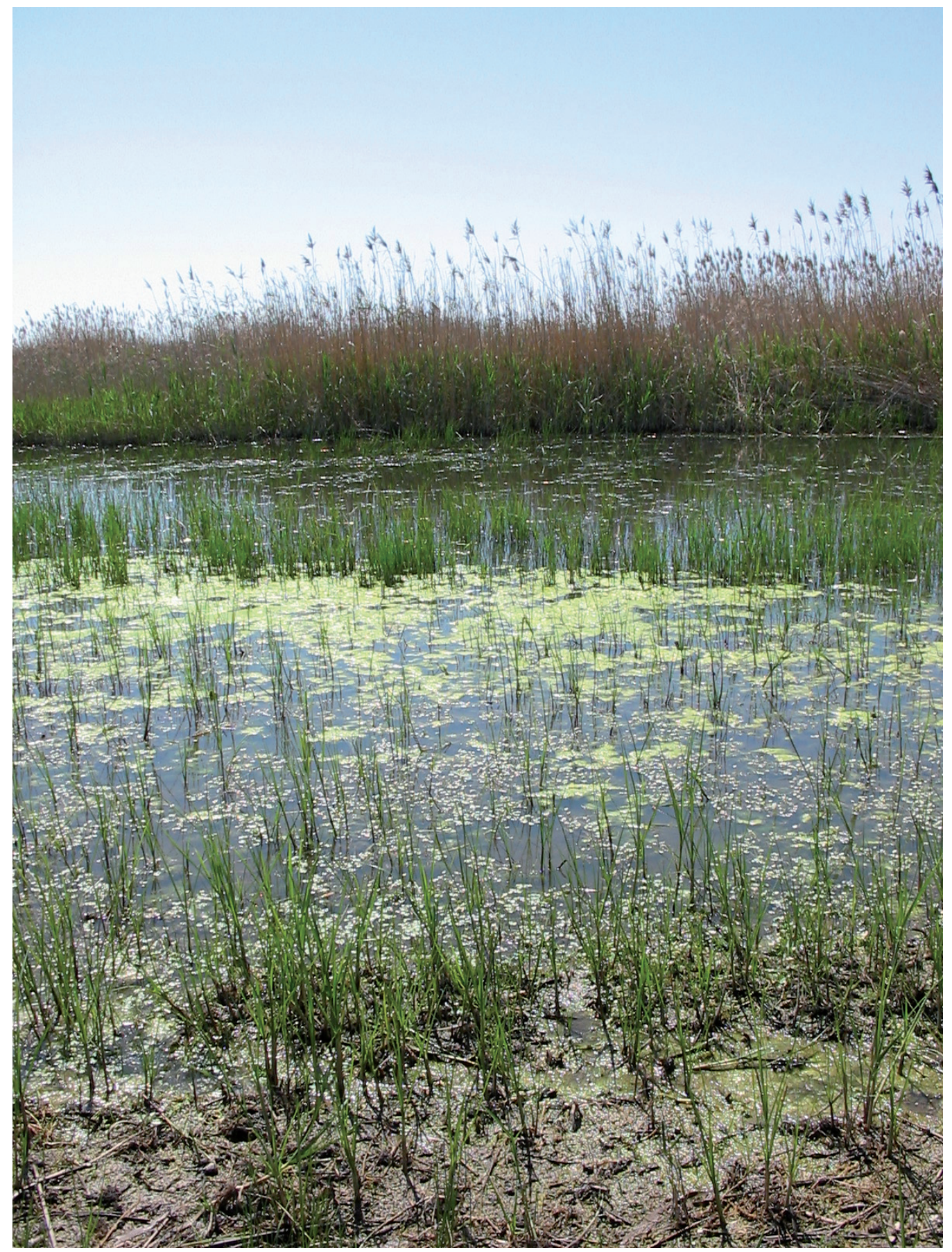

Fig. 2 - The rush-bed of the Torre Flavia wetland. (Il giuncheto della Palude di Torre Flavia). Photo by Anna Guidi. 
All bird individuals were recorded by direct observation left and right from the observer that walked along the longitudinal mid-line of the transect. We assigned the values 1 to each individual record (Bibby et alii, 2000). When occurring, the vegetation along the transect was mainly lower than $30 \mathrm{~cm}$ and we assumed that detection probability was uniform for all the bird individuals occurring in the area (Boulinier et alii, 1998). Birds in flight were not checked. The utilized method did not permit the sampling of individuals belonging to species with crepuscular and nocturnal activity (Bibby et alii, 2000).

\section{Data analysis}

Data obtained in each visit were elaborated in 6 bimonthly periods (three visits per month, for a total of 36 visits). We calculated:

- species richness $(\mathrm{S})$, as the total number of species checked in each bimonthly period;

- normalized species richness, utilizing the Margalef index as $\mathrm{Dm}=(\mathrm{S}-1) / \log \mathrm{n}$, where $\mathrm{S}$ is the number of species sampled and $\mathrm{n}$, the number of sampled individuals (Magurran, 2004);

- total abundance (n) and mean abundance (mean, and standard deviation) of each species, this last expressed as

Tab. 1 - Mean species abundance (mean; and standard deviation, s.d.), expressed as n. individuals $/ \mathrm{km}^{-1} / \mathrm{visit}$, in the 6 bimonthly periods along the 2007 yearly cycle. S: species richness; Dm: normalized species richness (Margalef index), n: total abundance. / Abbondanza media delle specie (media e deviazione standard, s.d.), espressa come individui $/ \mathrm{km}^{-1} /$ visita, nei 6 periodi bimestrali durante il ciclo annuale 2007. S: ricchezza di specie; Dm: ricchezza normalizzata di specie (indice di Margalef), n: abbondanza totale.

\begin{tabular}{|c|c|c|c|c|c|c|c|c|c|c|c|c|}
\hline \multirow[b]{2}{*}{ Species } & \multicolumn{2}{|c|}{ Jan-Feb } & \multicolumn{2}{|c|}{ Mar-Apr } & \multicolumn{2}{|c|}{ May-Jun } & \multicolumn{2}{|c|}{ Jul-Aug } & \multicolumn{2}{|c|}{ Sep-Oct } & \multicolumn{2}{|c|}{ Nov-Dec } \\
\hline & mean & (s.d.) & mean & (s.d.) & mean & (s.d.) & mean & (s.d.) & mean & (s.d.) & mean & (s.d.) \\
\hline Ardea cinerea & 0 & - & 0.17 & $(0.41)$ & 0 & - & 0 & - & 0 & - & 0 & - \\
\hline Anser anser & 0.17 & $(0.41)$ & 0 & - & 0 & - & 0 & - & 0 & - & 0 & - \\
\hline Anas platyrhynchos & 0.33 & $(0.82)$ & 0 & - & 0 & - & 0 & - & 0 & - & 0 & 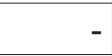 \\
\hline Charadrius dubius & 0 & - & 1.17 & (1.47) & 0.67 & $(0.82)$ & 0 & - & 0 & - & 0 & - \\
\hline Charadrius alexandrinus & 0 & - & 0.17 & $(0.41)$ & 0.17 & $(0.41)$ & 0 & - & 0 & - & 0.50 & $(0.76)$ \\
\hline Pluvialis squatarola & 0 & - & 0 & - & 0 & - & 0 & - & 0 & - & 0.17 & $(0.37)$ \\
\hline Actitis hypoleucos & 0 & - & 0 & - & 0 & - & 0.83 & $(2.04)$ & 0 & & 0 & \\
\hline $\begin{array}{l}\text { Chroicocephalus } \\
\text { ridibundus }\end{array}$ & 0.50 & $(0.55)$ & 0 & - & 0 & - & 0.17 & $(0.41)$ & 26.83 & $(60.50)$ & 0.83 & $(1.07)$ \\
\hline Larus michahellis & 0 & - & 0 & - & 0.17 & $(0.41)$ & 1.17 & $(2.86)$ & 0.17 & $(0.41)$ & 0 & 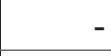 \\
\hline Galerida cristata & 0 & - & 0.83 & $(0.75)$ & 0.67 & $(0.82)$ & 0 & - & 0 & - & 0.17 & $(0.37)$ \\
\hline Anthus pratensis & 0.17 & $(8.41)$ & 4.17 & $(6.21)$ & 0 & - & 0 & - & 0.17 & $(0.41)$ & 1.17 & $(1.07)$ \\
\hline Motacilla flava & 0 & & 0.33 & $(0.82)$ & 0 & - & 0 & - & 0 & & 0 & \\
\hline Motacilla alba & 0.67 & $(0.82)$ & 1.00 & $(1.26)$ & 0.67 & $(0.82)$ & 0.50 & $(1.22)$ & 1.00 & $(1.10)$ & 1.17 & $(1.21)$ \\
\hline Erithacus rubecula & 0.17 & $(0.41)$ & 0 & - & 0 & - & 0 & - & 0 & - & 0.17 & $(0.37)$ \\
\hline Saxicola torquatus & 0.17 & $(0.41)$ & 0.50 & $(1.22)$ & 0 & - & 0 & - & 1.00 & $(1.67)$ & 0.17 & $(0.37)$ \\
\hline Oenanthe oenanthe & 0 & - & 0 & - & 0 & - & 0 & - & 0.17 & $(0.41)$ & 0 & - \\
\hline Cisticola juncidis & 0 & - & 0.17 & $(0.41)$ & 0.17 & $(0.41)$ & 0 & - & 0.17 & $(0.41)$ & 0.17 & $(0.37)$ \\
\hline Phylloscopus collybita & 0 & - & 0 & - & 0 & - & 0 & - & 0 & - & 0.67 & $(1.11)$ \\
\hline Pica pica & 0 & - & 0 & - & 0.17 & $(0.41)$ & 0 & - & 0 & - & 0 & - \\
\hline Corvus cornix & 1.33 & $(1.97)$ & 0.50 & $(1.22)$ & 0.33 & $(0.52)$ & 2.00 & $(2.28)$ & 0.67 & $(1.63)$ & 0 & - \\
\hline Passer domesticus & 0 & - & 0 & - & 2.67 & $(3.33)$ & 1.00 & $(1.26)$ & 0 & - & 0 & - \\
\hline Fringilla coelebs & 0 & - & 0 & - & 0 & - & 0 & - & 0 & - & 0 & - \\
\hline Carduelis cannabina & 0 & - & 0 & - & 0 & - & 0 & - & 0 & - & 1 & $(2.24)$ \\
\hline Carduelis chloris & 0.17 & $(0.41)$ & 0 & - & 0.17 & $(0.41)$ & 0 & - & 0 & - & 0 & 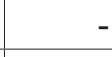 \\
\hline Emberiza schoeniclus & 0 & - & 0.17 & $(0.41)$ & 0 & - & 0 & - & 0 & - & 0 & - \\
\hline $\mathrm{S}$ & s & 9 & 1 & 1 & 1 & 0 & 6 & 6 & & 8 & & 11 \\
\hline $\mathrm{Dm}$ & 7. & 18 & 5. & 72 & 5. & 83 & 3. & 26 & & .1 & & .38 \\
\hline $\mathrm{n}$ & 3 & 4 & 5 & 6 & 3 & 5 & 3 & 4 & & 81 & & 37 \\
\hline
\end{tabular}


number individuals/km-1 per visit, for each bimonthly period;

We elaborated data for each LHT and for each bimonthly period. Each individual bird was taken as a sampling unit. Taxonomic nomenclature follows AERC TAC (2003).

Given that these data did not follow a normal distribution, differences in mean abundance among bimonthly periods were tested with the Kruskal-Wallis test. To evaluate the significance of differences among total number of individual sampled in the three LHTs, the $\chi^{2}$ test ( 2 d.f.) was applied, only on species with $>20$ total occurrences. Significance levels were set at $p<0.05$ and $p<0.01$. We used statistical package SPSS 13.0 for Windows.

\section{RESULTS AND DISCUSSION}

I observed 377 individuals belonging to 25 species (Table 1). Species richness ranged from 6 (July-August period) to 11 species (November-December and MarchApril) and Margalef index from 3.1 (September-October) and 3.26 (July-August) to 7.18 (January-February). Total abundance ranged from 34 (January-February and JulyAugust) to 181 (September-October; among them 161 individuals belonging to a flock of Chroicocephalus ridibundus). DUN was the richest LHT (also normalizing with Margalef index), SEA and SAN the poorest (Table 2).

Two locally sedentary species, Motacilla alba and Corvus cornix, occurred at least in five bimonthly periods. A wide set of locally wintering species occurred only in autumn-winter period (November-February): Anser anser, Anas platyrhynchos (also locally breeder; Battisti, 2006), Pluvialis squatarola, Erithacus rubecula, Phylloscopus collybita, Carduelis cannabina, while another set occurred in spring-summer period (March-June): Ardea cinerea, Charadrius dubius (locally breeding; Biondi et alii, 2000), C. alexandrinus, Galerida cristata (these last two, occurring also in winter), Motacilla flava, Pica pica, Carduelis chloris, Emberiza schoeniclus. Larus michaellis and Actitis hypoleucos occurred only in late spring and/ or in summer period. Oenanthe oenanthe occurred only in late summer.

Chroicocephalus ridibundus, Anthus pratensis, Motacilla alba, Corvus cornix and Passer domesticus were the more abundant species around the year $(>20$ individual sampled), all with significant differences in their frequency between LHTs (respectively, $\chi^{2}=744, \chi^{2}=118$, $\chi^{2}=97.2, \chi^{2}=124, \chi^{2}=91.8$, all $\left.\mathrm{p}<0.01\right)$. Chroicocephalus ridibundus, Corvus cornix and Passer domesticus were sampled prevalently in the intermediate SAN zone; Anthus pratensis and Motacilla alba occurred mainly in SAN and DUN zones. A large set of Passeriformes occurred only in the inner DUN zone. Ardea cinerea, Anser anser, Pluvialis squatarola occurred occasionally only in the SEA zone (Table 2).

The assemblage occurring on this Mediterranean beach include a heterogeneous group composed by locally sedentary breeders, wintering and migratory species (see Battisti \& Sorace, 2006) that utilize the beach as breeding, stop-over and/or foraging site.
Tab. 2 - Total occurrences (individuals) sampled around the 2007 yearly cycle. SEA: seashore area; SAN: intermediate sandy zone; DUN: inner embryonic shifting dunes. S: species richness; Dm: normalized species richness (Margalef index), n: total abundance. / Numero totale di individui (occurrences) rilevati durante il ciclo annuale 2007. SEA: battigia; SAN: zona sabbiosa intermedia; DUN: dune mobili embrionali interne. S: ricchezza di specie; Dm: ricchezza normalizzata di specie (indice di Margalef), n: abbondanza totale.

\begin{tabular}{|c|c|c|c|}
\hline & \multicolumn{3}{|c|}{ LHT } \\
\hline Species & SEA & SAN & DUN \\
\hline Ardea cinerea & 1 & 0 & 0 \\
\hline Anser anser & 1 & 0 & 0 \\
\hline Anas platyrhynchos & 0 & 1 & 1 \\
\hline Charadrius dubius & 1 & 6 & 4 \\
\hline Charadrius alexandrinus & 3 & 2 & 1 \\
\hline Pluvialis squatarola & 1 & 0 & 0 \\
\hline Actitis hypoleucos & 5 & 0 & 0 \\
\hline Chroicocephalus ridibundus & 5 & 165 & 0 \\
\hline Larus michahellis & 7 & 2 & 0 \\
\hline Galerida cristata & 0 & 1 & 9 \\
\hline Anthus pratensis & 0 & 16 & 21 \\
\hline Motacilla flava & 0 & 0 & 2 \\
\hline Motacilla alba & 3 & 22 & 10 \\
\hline Erithacus rubecula & 0 & 0 & 3 \\
\hline Saxicola torquatus & 0 & 2 & 9 \\
\hline Oenanthe oenanthe & 0 & 1 & 0 \\
\hline Cisticola juncidis & 0 & 0 & 4 \\
\hline Phylloscopus collybita & 0 & 0 & 4 \\
\hline Pica pica & 0 & 1 & 0 \\
\hline Corvus cornix & 0 & 27 & 2 \\
\hline Passer domesticus & 0 & 20 & 2 \\
\hline Fringilla coelebs & 0 & 0 & 1 \\
\hline Carduelis cannabina & 0 & 0 & 6 \\
\hline Carduelis chloris & 0 & 0 & 2 \\
\hline Emberiza schoeniclus & 0 & 0 & 3 \\
\hline $\mathrm{S}$ & 9 & 13 & 17 \\
\hline $\mathrm{Dm}$ & 5.59 & 4.95 & 8.31 \\
\hline $\mathrm{N}$ & 27 & 266 & 84 \\
\hline
\end{tabular}

Beaches represent patchy ecosystems with a different availability of resources in space and time. Different sets of species appeared to utilize the different LHTs each one with a specific availability of trophic resources (marine invertebrates and detritus in SEA, marine and anthropogenic detritus in SAN, vegetation and associated invertebrates in DUN).

DUN appeared the richest LHT, also normalizing species to individuals (Margalef index). The presence of vegetation and related soil patchiness with linked trophic 
resources permits the occurrence of a larger set of species, prevalently Passeriformes. In intermediate SAN zone, there is not vegetation and only detritus from marine sedimentation and human garbage is available: this zone showed a low richness with a prevalence of generalist species (e.g., Motacilla alba, Corvus cornix, Passer domesticus). In SEA zone we obtained a prevalence of non-Passeriformes (mainly Ciconiiformes, Anseriformes, Charadriiformes), due to availability of marine-related resources (invertebrates, detritus).

This preliminary study highlight as bird assemblages on sandy beaches may be characterized: i) from a low total and species-specific abundance, ii) from marked fluctuation in richness among bimonthly periods, and iii) from a high heterogeneity in composition with species different at ecological- and phenological-level due to high spatial heterogeneity and dynamism of these peculiar ecosystems.

\section{REFERENCES}

Acosta A.T.R. \& Izzi C.F., 2006 - Analisi dei disturbi reali potenziali sulla flora e vegetazione dunale. In: Biodiversità, gestione, conservazione di un'area umida del litorale tirrenico: la palude di Torre Flavia. Battisti C. (a cura di). Provincia di Roma, Gangemi editore, Roma: 384-387.

AERC TAC, 2003 - AERC TAC Check-list of bird taxa occurring in western Palearctic region with distributional notes on subspecies. Available from: http:www. aerc.be

Battisti C., 2006 - Biodiversità, gestione, conservazione di un'area umida del litorale tirrenico: la Palude di Torre Flavia. Provincia di Roma, Gangemi editore, Roma.

Battisti C. \& Sorace A., 2006 - Check-list degli Uccelli aggiornata a novembre 2005. In: Biodiversità, gestione, conservazione di un'area umida del litorale tirrenico: la Palude di Torre Flavia. Battisti C. (a cura di). Provincia di Roma, Gangemi editore, Roma: 255269.

Battisti C., Aglitti C., Sorace A. \& Trotta M., 2006 - Water level and its effect on the breeding bird community in a remnant wetland in Central Italy. Ekologia, Bratislava, 25: 252-263.

Battisti C., Luiselli L., Pantano D. \& Teofili C., 2008 - On threats analysis approach applied to a Mediterranean remnant wetland: Is the assessment of human-induced threats related into different level of expertise of respondents? Biodiversity and Conservation, 16: 15291542.

Bibby C.J., Burgess N.D., Hill D.A. \& Mustoe S., 2000 Bird Census Techniques. $2^{\text {nd }}$ edition Academic Press, London.

Biondi M., Pietrelli L., Guerrieri G., Corso A. \& Grussu M., 2000 - Il Corriere piccolo, Charadrius dubius, nell'Italia centrale e meridionale. Rivista italiana di Ornitologia, 70: 97-114.

Blasi C. \& Michetti L., 2005 - Biodiversità e Clima. In: Stato della biodiversità in Italia. Contributo alla strategia nazionale per al biodiversità. C. Blasi, L. Boitani,
S. La Posta, F. Manes \& M. Marchetti (eds.). Ministero dell'Ambiente e della Tutela del territorio, F.lli Palombi editori, Roma.

Blondel J., Ferry C. \& Frochot B., 1970 - La méthode des Indices Ponctuels d'Abondance (I.P.A.) ou des relevés d'avifaune par "Stations d'écoute". Alauda, 38: 5571.

Boulinier T., Nichols J.D., Sauer J.R., Hines J.E. \& Pollock K.H., 1998 - Estimating species richness: the importance of heterogeneity in species detectability. Ecology, 79: 1018-1028.

Brown A.C. \& McLachlan A., 2002 - Sandy shore ecosystems and the threats facing them: some predictions for the year 2025. Environmental Conservation, 29: 62-77.

Fauth J.E., Bernardo J., Camara M., Resetarits W.J., van Buskirk J. \& McCollum S.A., 1996 - Simplifying the jargon of community ecology: a conceptual approach. American Naturalist, 147: 282-286.

Guidi A., 2006 - Introduzione alla flora e alle comunità vegetali. In: Biodiversità, gestione, conservazione di un'area umida del litorale tirrenico: la Palude di Torre Flavia. Battisti C. (a cura di). Provincia di Roma, Gangemi editore, Roma: 169-188.

Komar P.D., 1998 - Beach processes and sedimentation. Prentice Hall, New Jersey.

McLachlan A. \& Brown A.C., 2006 - The ecology of sandy shores. Academic Press, Burlington, MA, USA.

Magurran A., 2004 - Measuring biological diversity. Blackwell Publishing, Malden, MA.

Schlacher T.A., Schoeman D.S., Lastra M., Jones A., Dugan J., Scapini F. \& McLachlan A. 2006 - Neglected ecosystems bear the brunt of change. Ethology Ecology and Evolution, 18: 349-351.

Sutherland W.J., 2006 - Ecological Census techniques. Blackwell, London.

Tomaselli R., Balduzzi A. \& Filippello S., 1973 - Carta Bioclimatica d'Italia. Collana verde, 33. Ministero Agricoltura e Foreste, Roma.

Williams J.S., Ward V.I. \& Underhill L.G., 2004 - Waders respond quickly and positively to the banning of off-road vehicles from beaches in South Africa. Wader Study Group Bulletin, 104: 79-81. 